Сумський державний університет,

м. Суми, Україна

v_m_vlas@ukr.net

\title{
УКРАЇНСЬКЕ ТОВАРИСТВО ПРОСВІТА В ЗАГРЕБІ У 1922-1941 PP. (ОРГАНІЗАЦІЙНА СТРУКТУРА)
}

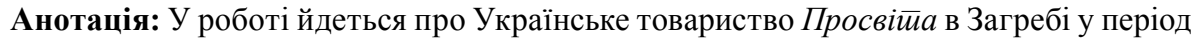
між Першою та Другою світовими війнами. Крізь призму документів і матеріалів українських, сербських і хорватських архівів та емігрантської преси показані зміни організаційної структури товариства. Охарактеризовано склад центральної організації товариства в Загребі та Белграді, визначено хронологію появи його філій і представництв у Боснії, Македонії, Сербії та Хорватії.

Ключові слова: Белград, Загреб, Королівство сербів, хорватів і словенців, русини, українська еміграція, Українське товариство Просвій, Югославія.
\end{abstract}

У період між Першою та Другою світовими війнами в Королівстві сербів, хорватів і словенців (КСХС) найбільш сприятливі умови для організованого життя українських емігрантів склалися в Хорватії. Хорвати, які обстоювали тоді ідею федералізації Югославії, прихильно ставилися до боротьби українців за власну державність та культуру. Ще за часів Австро-Угорщини в Загребі проживало чимало вихідців із Західної України. На початку 1920-х рр. вони складали більшість серед українських емігрантів у цьому місті. Частина $з$ них мала вищу освіту або навчалася в Загребському університету. Рівень їхньої національної свідомості був досить високим. Саме тому в Хорватії і виникла перша громадська організація міжвоєнної української політичної еміграції в КСХС - Українське товариство Просвійа (УТП, Ukrajinsko društvo prosvjete) у Загребi.

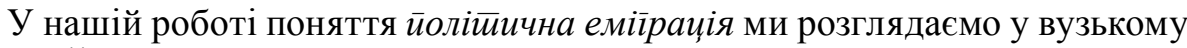
сенсі. Йдеться про ту частину української еміграції, яка була політично вмотивована, ідеологічно визначена, організаційно структурована та сповідувала ідею відновлення української державності в різних її формах. Тому автор ставить собі за мету розкрити особливості організаційної структури 


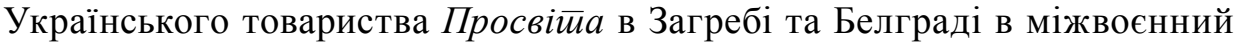
період. У роботі не йдеться про основні напрямки діяльності УТП.

29 червня 1922 p. ${ }^{1}$ ініціативна група у складі Івана Будза, Василя Войтанівського, Івана Дрогобецького, Івана Ерделі, Антона Жука, Івана Калая, М. Коміліча, Іллі Крайцара, Федора Лабоша, Павла Луцького, Богдана Макарушки, М. Осідача, Олеся Спенула, Йосипа Філаса, Григорія Шевчика та Петра Штурман-Зайченка скликала установчі збори, які схвалили статут УТП. До управи обрали І. Будза (голова), В. Войтанівського (заступник), I. Калая (секретар), Й. Філаса (скарбник), А. Жука (бібліотекар), наглядової ради (ревізійна комісія) - Клименка й I. Крайцара (HR-HDA, 1353-3399: 1525). Засновники УТП взяли за зразок статут львівської Просвітии. Головною метою організації було об'єднання на культурно-освітній основі всіх українців, які проживали на території КСXC (HR-HDA, 1353-3399: 19).

Виникнення нової громадської організації викликало занепокоєння у керівництва русинської організації Руське нарояно-йросвітине ииоварисииво (РНПД, Руске народне просвитне друштво) в м. Рускі Керестур. Заступник голови управи РНПД о. Юрій Біндас звернувся листом до управи УТП, в якому висловив занепокоєння щодо можливої конкуренції двох товариств. В. Войтанівський переконав його у протилежному. На його думку, товариства не могли конкурувати, оскільки РНПД опікувалося переважно бачвансько-сремськими русинами, а УТП як загальноукраїнська організація займалося поширенням української культури та підвищенням національної свідомості політичних емігрантів й українців, які проживали в Хорватії та Боснії. З'ясування позицій на початку виникнення протиріч між двома організаціями не призвело до ворожнечі (Латяк, 2002: 52-53).

Незважаючи на те, що статут УТП був досить поміркованим щодо національного питання, Міністерство внутрішніх справ КСХС затвердило його лише 7 лютого 1925 р. (HR-HDA, 1353-3399: 42)2. У травні того ж року була обрана нова управа. До її складу увійшли І. Будз (почесний голова), В. Войтанівський (голова), Всеволод Лаврів (заступник), Григорій Шевчик (секретар), Федір Лабош (скарбник), Анатолій Майлушевський (бібліотекар), ревізійної комісії - I. Каляй та Олесь Степун. Запасними членами управи та комісії обрали Миколу Камінецького, Осипа Костельника й А. Жука (До-

1 У науковій літературі зустрічаються помилки щодо дати (день місяця або рік) заснування товариства. Див.: Козлитин В. Д. Русская и украинская эмиїрация в Юїославии (1919-1945 їі.), Харьков, с. 252; Патер I. Г. Українська еміграція до Південної Європи (за матеріалами Центрального державного історичного архіву України у Львові), Вісник Львівської комериійно акаgемії, сер.: гуманітарні науки, Львів, 2011, вип. 10, с. 184.

$2 €$. Пащенко стверджує, що до затвердження статуту УТП у Загребі діяло як секція хорватського товариства Domagoj. Див.: Пащенко Є. Українська інтелігенція і розвиток хорватської україністики,

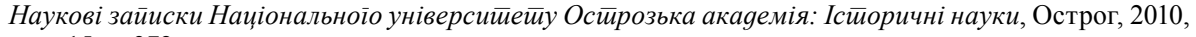
вип. 15, с. 372. 
писі, 1925: 4). Активність УТП у Загребі виявилася у культурно-освітній діяльності й ознайомленні хорватської громадськості з українською національною справою.

Найбільш активною й організованою силою української еміграції на початку 1920-х рр. була студентська молодь. Чимало уродженців України навчалося в югославських вищих навчальних закладах. Але якщо в Белграді вони перебували «ӣig ойікою» російських організацій (Лимар, 1923: 68-69), то в Загребському університеті українці змогли створити студентську організацію. Вперше думку про заснування власної спілки студенти Загребського університету висловили 28 січня 1922 р., а 12 травня того ж року статут Української сйуденииської іромаяи у Заїребі (УСГ, Ukrajinsko studentsko društvo u Zagrebu) був поданий до сенату університету на затвердження. 17 травня відбулися установчі збори УСГ (Роговий, 2008: 219). У них взяли участь Дмитро Бережний, Яків Болобан, Олександр Горчинський, Іван Горянський, Григорій (Грегор) Калюжний, Богдан і Любомир Макарушки, Володимир Моклович, Павло Луцький, Микола Осідач та Микола Юрійчук. До складу управи були обрані Л. Макарушка (голова), О. Горчинський (заступник), П. Луцький (секретар), І. Горянський (скарбник), М. Юрійчук (бібліотекар) (HR-HDA, 1353-3908: 6). 9 лютого 1923 р. югославська влада затвердила статут УСГ (HR-HDA, 1353-3908: 23). Отже, на той момент Українська студентська громада у Загребі була єдиною легальною організацією українських емігрантів у КСХС.

На початку червня 1922 р. до Громади належало 18 студентів, в тому числі із Наддніпрянської України - 4, Східної Галичини - 11, Бачки, Срема і Боснії - 3. 3 них 16 осіб були колишніми військовими. Під час Першої світової війни та Української революції 1917-1921 рр. вони служили у військових формуваннях Австро-Угорщини (8 осіб), Росії (4), УНР (4), ЗУНР (8) та Червоній Українській Галицькій Армії (5). На 20 червня 1922 р. у складі УСГ перебувало вже 28 членів. Навесні наступного року у зв'язку з виїздом більшості студентів-галичан із Загреба була обрана нова управа у складі Сергія Сухорукова (голова), Всеволода Лавріва (заступник), Григорія Бордукало (секретар), Г. Калюжного (скарбник), Григорія Павлоградського та Ірини Дятків (члени). Членами-фундаторами УСГ були відомий громадський діяч, професор Стефан Лукіянович та голова УТП в Загребі В. Войтанівський (Роговий, 2008: 219-221). У 1922-1923 рр. Громада співпрацювала із загребською Просвітиою у культурно-освітній сфері, проте "вже на-

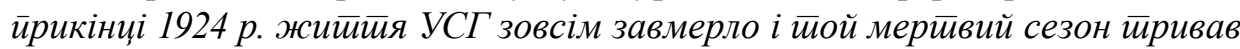
go 1932 p.” (ЦДАВО, 3905-2-165: 8). Зауважимо, що у липні 1927 р. Українська студентська спілка в Загребі підписала протест українських студентських

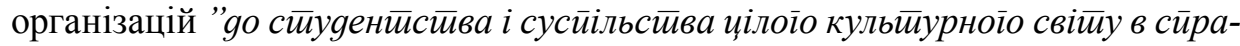


ві вбивстива Головноїо Ойамана С. В. Пейлюри”. На той момент УСГ мала 14 членів. Головою управи був В. Могильницький, секретарем - Бородавченко (Протест, 1927: 7).

3 покращенням правового становища емігрантів, припиненням адміністративної діяльності російських організацій біженців, позбавленням певних обмежень щодо пересування територією країни та зміни місця проживання в середині 1920-х рр. кількість емігрантів взагалі й українських зокрема в Белграді збільшилася. Делегат від українських організацій в Югославії на I Конференції української еміграції, що відбулася у 1929 р. в Празі,

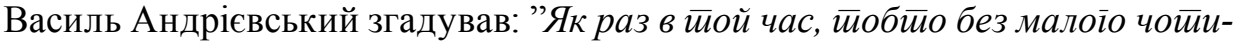

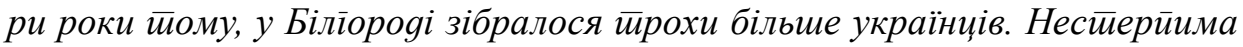
аймосфера, яку ииворила російська реакція на чолі з своєю Комісією йо сиравах біженців, чи як самі росіяне називали ї "Чорна Чека", ирохи розвіялась, з'явилися кращі умови иеребування украйнців у самому Білїороgі, а заразом з иим і кращі умови для ираці. Найурально, що в біліоородських ук-

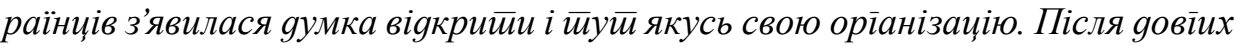

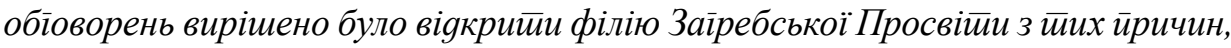

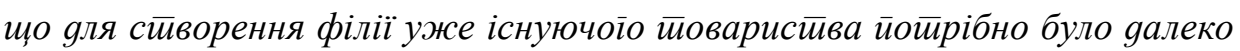

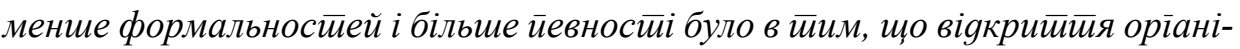
заиії буgе яозволено” (ЦДАГО, 269-2-258: 28).

Крім того, із Загреба виїхали провідні діячі УТП І. Будз, В. Войтанівський, Г. Шевчик, М. Юрійчук та інші. 29 січня 1926 р. у Белграді була заснована філія УТП. До їі управи були обрані І. Будз (голова), Володимир Шухевич, Павло Павлович-Шура (заступники), В. Андрієвський (секретар), Володимир Вільковський (бібліотекар), Мар'ян Тумир (скарбник) та Іван Радченко (референт музично-драматичного відділу). Адреса філії: I. Budz, «Putnik», Kolarčeva 1, Beograd (Різні вісти, 1926: 4). Пізніше управа філії УТП знаходилася у приміщенні по вул. Нєгушева (Njeguševa), 51 (ЦДАГО, 269-2-268: 163зв). Упродовж 2 років філія діяла більш-менш злагоджено, без внутрішніх конфліктів, була активною та чисельною. До неї записувалися і групи українців, які проживали в інших містах Сербіі. Так, у січні 1928 р. філія УТП у Белграді мала близько 150 членів, в тому числі 40 галичан, iii нелегальна філія у Новому Саді - 22 члени, групи українців у Смедерево - 7, Великому Бечкереку - 15, Осієку - до 20 осіб із Наддніпрянщини та 70 3 Кубані, тоді як центральна організація в Загребі налічувала лише 30 членів (ЦДАГО, 269-2-262: 35). Тому 30 січня того ж року управа філії УТП в Белграді повідомила МВС про рішення загальних зборів УТП у Загребі від 27 
листопада 1927 р. перенести місце перебування центрального управління Товариства до Белграда (АJ, 14-64-204: 97)³.

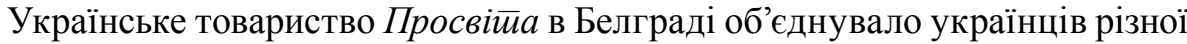
політичної орієнтації. Якщо голова управи І. Будз спочатку був прихильником політичних структур ЗУНР в еміграції та на західноукраїнських землях, публікувався в берлінському часописі Украӥнський Прайор та львівській пресі, згодом орієнтувався на гетьмана Павла Скоропадського, то секретар управи В. Андрієвський підтримував Уряд УНР в еміграції, його статті друкувалися на сторінках паризького тижневика Тризуб. До складу УТП входили також гетьманці та так звані малороси 4 . 3 часом ці розбіжності у політичних симпатіях викликали певне напруження між членами управи УТП. Ситуація загострилася з приїздом із Стамбула до Белграда прихильника гетьмана П. Скоропадського Миколи Зоц-Кравченка, який намагався включити до складу Просвіиии якомога більше малоросів, запозичити для УТП гроші у російських емігрантських організацій та сербської влади. 3 обранням у лютому 1928 р. нової управи УТП, у складі якої переважали наддніпрянські українці на чолі з В. Андрієвським, відбувся розлад у робо-

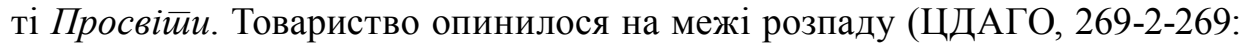
198).

У червні 1928 р. при УТП почав діяти драматичний гурток на чолі 3 Михайлом Манглером. Згодом він перетворився на драматичну трупу

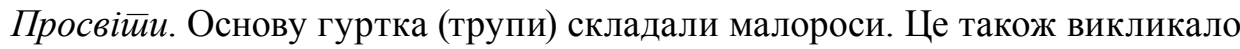
невдоволення частини членів, які виступали за політизацію діяльності Просвіти и (ЦДАГО, 269-2-258: 29-30).

3 метою не допустити, на думку В. Андрієвського, компрометації української справи в КСХС частина членів УТП в Белграді у вересні 1928 р. вийшла зі складу Просвіти и та створила Українську громаду (УГ). Проте не всі прихильники УНР в Югославії схвалювали такий крок колег. Голова управи філії УТП в Новому Саді полковник Олександр Колтоновський у листі до представника військового міністра УНР на Балканах Василя Филоновича від 15 червня 1928 р. стверджував, що треба було зробити все, щоб:

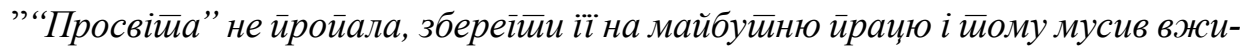

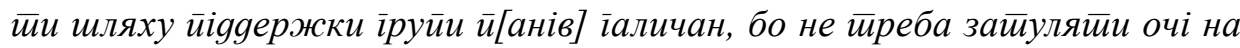

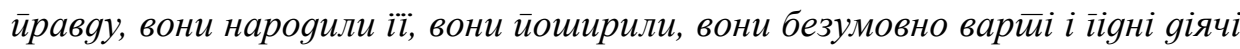

3 В українській емігрантській пресі зустрічаються помилки щодо дати загальних зборів УТП у Загребі про перенесення центрального офісу Товариства до Белграда. Замість 27 листопада вказано 27 вересня. Див.: Хорив. Українська еміграція в Югославії, Українські вістии, Берлін, 1943, № 3 (7 лютого), с. 6.

4 Йдеться про уродженців України, які, опинившись в еміграції, не виокремлювали себе політично від російської еміграції і Росії взагалі та визнавали свою окремішність від росіян лише у галузі мови та культури. 


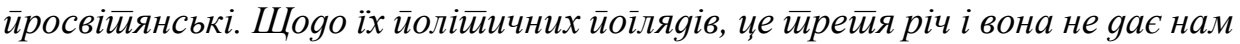

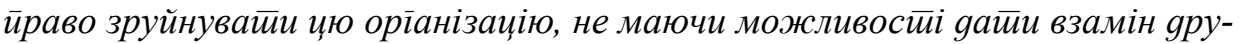
їy...” (ЦДАГО, 269-2-269: 198).

Відносини УТП в Белграді з новоутвореною організацією не були дружніми та взаємовигідними. Восени 1928 р. на сторінках української (Діло, Тризуб) та югославської (Обзор) преси з'явилися критичні статті про опонентів. Спроби з боку керівництва Просвіти и в особі колишнього сотника військово-морської авіації, викладача 2-ої Белградської гімназії Володимира Вільковського залучити до справи примирення з керівництвом УГ В. Филоновича (ЦДАГО, 269-2-271: 14, 118-121) й О. Колтоновського (ЦДАГО, 269-2-275: 152-153) не дали позитивних результатів. Надалі обидва товариства діяли окремо, конкуруючи між собою.

У червні 1932 р. югославська влада заборонила центральну організацію УТП в Белграді. Невдовзі на сторінках друкованого органу Української партії соціалістів-революціонерів з'явилася публікація, в якій Державний Центр УНР й особисто представника військового міністра УНР на Балканах В. Филоновича звинуватили у розкладі белградської Просвіти $и$ та припиненні її діяльності (3 громадського, 1932: 26). Члени філії УТП у Новому Саді відкинули всі звинувачення у причетності полковника до заборони белград-

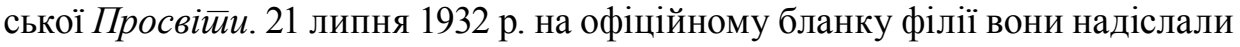
В. Филоновичу листа 3 підтримкою його діяльності з об'єднання українських організацій в Югославії (ЦДАГО, 269-2-278: 5-6). У липні того ж року УГ Кобзар у Смедерево також спростувала всі закиди редакції журналу Tpygoва Україна до В. Филоновича щодо причетності до закриття белградської

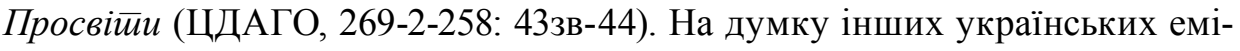
грантів, югославська влада припинила діяльність УТП через його комунофільстиво (Хорив, 1943b: 6; Liskij, 1990-2000: 294).

УТП в Белграді мала декілька філій. У 1927 р. у м. Нові Сад сформува-

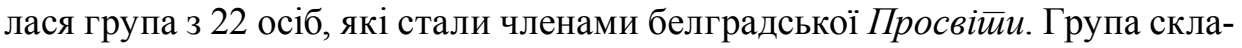
далася з уродженців Наддніпрянської України (Київщина, Полтавщина, Харківщина). У січні наступного року вона вирішила відкрити філію УТП у Новому Саді. Ї̈і організатором був полковник О. Колтоновський. 1 березня 1928 р. статут філії був затверджений (ЦДАГО, 269-2-269: 28-38зв, 78). У серпні того ж року управа філії домовилася з управою Новосадської кубанської станиці ім. кошового отамана 3. Чепіги (підпорядковувалася генералу І. Д. Павліченку) про спільні дії в культурно-освітній і громадській сферах, економічну і моральну підтримку (ЦДАГО, 269-2-270: 31). Навесні 1929 р. у зв'язку з виїздом частини членів філії на роботу до інших місцевостей їх кількість зменшилася спочатку до 19, а потім до 15 осіб. 3 березня 1929 р. до складу їі управи входили О. Колтоновський (голова), Б. Мартос (секретар), 
М. Ревич (скарбник), Олекса Жаботинський (бібліотекар) (ЦДАГО, 269-2-272: 163в, 28). У 1929-1930 рр. філія виступала за об'єднання всіх українських сил у країні, брала участь у нарадах зі створення Союзу українських організацій в Югославії (ЦДАГО, 269-2-276: 8). Але у зв'язку із виїздом у червні 1931 р. на роботу до Сирії О. Колтоновського активність організації зменшилася, а з 1933 р. філія ледве животіла (ЦДАГО, 269-2-278: 50зв). 3 лютого 1932 р. до складу управи входили Іван Венгрженовський (голова), О. Жаботинський (заступник), Б. Мартос (секретар), М. Вітчинкін (скарбник), Бурдзиновський (бібліотекар) (Хроніка, 1932: 15). У лютому наступного року керівний склад філії змінився: О. Жаботинський (голова), М. Гавва (заступник), Б. Мартос (секретар), Вітчинкін (скарбник), Бурдзиновський (бібліотекар). До ревізійної комісії обрали І. Венгрженовського та П. Загоруйка (Хроніка, 1933: 30).

У 1928 р. у м. Скоп’є виник напівлегальний український гурток у складі 6 осіб - членів УТП в Белграді. Очолив його Олександр Петренко. 3 метою набуття статусу філії група подала на затвердження статут організації (ЦДАГО, 269-2-269: 114зв-115зв). Лише влітку 1931 р. він був затверджений (ЦДАГО, 269-2-277a: 50). Проте філія УТП у Скоп'є так і не виявила активності. У середині 1930-х рр. через пасивність їі членів філія фактично припинила свою діяльність. Спроба перетворити філію на Українську громаду також не дала позитивних результатів (ЦДАГО, 269-2-282: 177). До керівного складу філії у різний час належали О. Петренко, І. Будз, В. Вільковський і Д. Байбузенко.

Філія УТП у Загребі до початку 1930-х рр. не була активною й обмежувалася поодинокими культурно-освітніми заходами. Але $з$ ліквідацією белградської УТП місцеві просвітяни вирішили відновити центральну організацію УТП у Загребі. Вперше така ідея була висловлена у червні 1932 р., але через арешт майна Просвіти $и$ в Белграді її реалізація розтягнулася на рік. 15 червня 1933 р. загальні збори філії УТП у Загребі схвалили нову редакцію статуту, яку місцева хорватська влада затвердила 27 жовтня того ж року (HR-HDA, 1353-3399: 59).

Активізації діяльності УТП у Загребі сприяло і те, що у 1932 р. до місцевого університету вступило декілька студентів із Західної України, які прибули до "gешевої” Югославії з Праги і Левена (Лувена) $)^{5}$. Як згадував Євген Мацях, 'Праїа була 'заяороїа', а Лювен з йоїо 'ешиикою' на меgичному факультеиеиі 'засхолястичний”' (Мацях, 2002: 51). Ці студенти і відновили Українську стйgенйську іромаgу, проте не як самостійну організацію, оскільки ініціативна група налічувала менше 10 студентів, а секцію УТП

5 Левен (нід. Leuven, фр. Louvain) - місто в Бельгії, в якому знаходиться найстаріший в країні університет. У міжвоєнний період у ньому навчалося декілька десятків українських емігрантів. 
(рішення управи УТП від 19 лютого 1934) (ЦДАВО, 4465-1-312: 1зв). У травні 1936 р. УСГ мала вже 25 членів. До складу її управи входили Осип Коропей (голова), Андрій Пелліх (заступник), Іван Яцусь (секретар), Осип Мисак (скарбник), Василь Барицький (бібліотекар), ревізійної комісії - Михайло Степчишин, Свген Мацях та Григорій Гарбачевський. У листопаді 1937 р. була обрана нова управа у складі М. Степчишина (голова), О. Мисака (заступник), I. Яцуся (секретар), С. Мацяха (скарбник), В. Барицького (бібліотекар), ревізійна комісія - О. Корепея, Ольги Коліщицької та Романа Стадника (3 журналів, 2008: 134-135, 165).

У березні 1932 р. в Празі відбулося святкування 20-ліття Українського пласту. На ньому були присутні і молоді українці із Загреба. Саме вони тоді і заснували українську групу пластунів. Того ж року на II Національному югославському джемборі (з’ізд) в Загребі через протест гостей із Польщі українську групу визнали складовою частиною делегації пластунів з Чехословаччини (Кульчицький, 1951: 34). У 1934 р. група була реформована у IX курінь старших пластунів Перелейні Союзу українських пластунів-емігрантів. Керівники куреня вели переговори із Союзом югославських пластунів про реєстрацію IX куреня самостійною організацією (3 нашого, 1934: 6). Але через неможливість легалізуватися 1935 р. курінь змушений був припинити своє існування. За час свого існування курінь перебував під

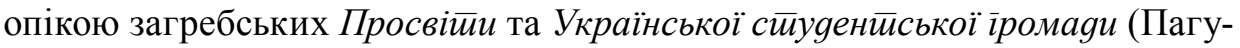
ангаре, 1936: 12-13). До складу курінної команди входили Є. Мацях (курінний), М. Степчишин (писар), О. Мисак (скарбник) (Короткий, 1936: 4).

У 1933 р. розпочався новий етап в історії загребської Просвійи. У діяльності УТП відбулися якісні та кількісні зміни. По-перше, Товариство намагалося поширити свій вплив не тільки серед українських політичних емігрантів й українців у Хорватії та Боснії, але і бачвансько-сремських русинів, які проживали у Воєводині (регіони Бачка і Срем). Склавши статут відповідно до нових вимог югославського законодавства, УТП в Загребі

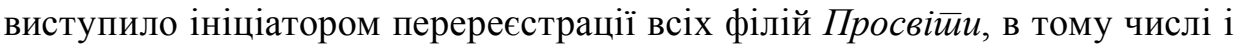
тих, які вважали своїм центром РНПД у Руському Керестурі. Загальні збори УТП, що відбулися у жовтні 1933 р., закликали місцевих українців вступити до нього, долучитися до організації курсів з ліквідації неписьменності та використовувати вдома тільки українську мову. Тоді ж оновилося і керівництво загребської Просвіии . До складу управи обрали В. Войтанівського (голова), Г. Калюжного (заступник), Михайла Степчишина (секретар), Василя Могильницького (скарбник), о. Михайла Костюка з Козарця, о. Івана Левицького із Старої Дубрави, д-ра Г. Шевчика з Кучева, М. Юрійчука 3 Оточца, д-ра Людвика Карманського із Загреба (члени), контрольної (реві- 
зійної) комісії - о. Михайла Фірака, д-ра Володимира Софієвського та Степана Гриба (Терлюк, 2002: 78-79).

По-друге, ширилася мережа філій. У середині 1930-х рр. були відкриті філії у Баня Луці, Козарці, Муїнцях, Прняворі, Штрбцях та представництва у Брезіку (відпоручник Петро Сливка), Гаєві (Остап Бородій), Дев'ятині (Петро Шабадин), Дервенті, Детляку (Антон Гралюк), Камениці (Свстахій Легенький), Каніжі (Петро Недогон), Кучеві (Г. Шевчик), Лішні (Микола Чорний), Сараєві, Сібіні (Осип Макарчук), Старій Дубраві (І. Левицький), Хорвачанах (Олекса Лаврів). 3 часом представництва перетворювалися на філії. У другій половині 1930-х рр. осередки УТП відкрилися і в інших міс-

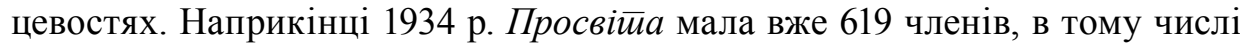
почесних -5 , фундаторів - 4, жертводавців - 12, звичайних -598 , 3-поміж них у Загребі - 63, Баня Луці - 106, Козарці - 80, Прняворі - 58, Муїнцях - 60, Штрбцях - 65, Брезіку - 17, Гаєві - 12, Старій Дубраві - 35, Детляку - 21, Лішні - 31, Камениці - 29, Дев’ятині - 15, Хорвачанах - 12, Сараєві - 4 (Liskij, 2008: 57-58). У вересні 1937 р. УТП мало 8 філій і близько 1 тис. членів (Liskij, 1990-2000: 297; Кулеба, 2007: 26).

Проте суцільного об'єднання філій під егідою загребського центру не відбулося. Декілька років фактично існувало дві Просвіти - у Загребі та Боснії. Перша, незважаючи на задекларовану у статуті аполітичність, орієнтувалася на хорватські політичні партії, що для українців Боснії, де переважали сербські політичні сили, мало б негативні наслідки в умовах гострої політичної боротьби за владу в центрі і на місцях. Друга під час виборчих кампаній намагалася бути нейтральною (Терлюк, 2002: 80-81). Велику ува-

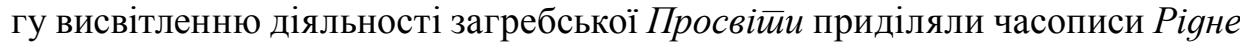
слово (з жовтня 1933 р., Пішкуревці, Дервента, Рускі Керестур) за редакцією о. М. Фірака, Украӥнський клич (з 7 червня 1934 р., Загреб) та Вісииник Укра-

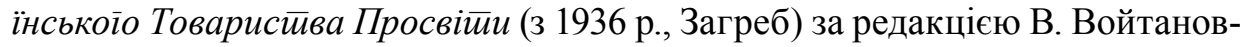
ського, а також періодично місцева газета Vrbaske novine (Баня Лука) (Liskij, 2008: 59). Боротьба між поміркованою частиною українців/русинів, яких в УТП уособлював М. Фірак, та її радикальною, націоналістичною частиною

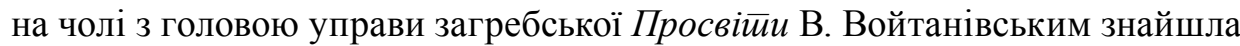
відображення на сторінках тогочасної української преси в Югославії (3 журналів, 2008: 111-114, 122-127).

Непорозуміння існувало і між центральною організацією УТП у Загребі та Прняворським і Баня-луцьким деканатами греко-католицької церкви, якій не подобалася діяльність загребської Просвіти з об'єднання усіх українців в Югославії, незалежно від конфесійної приналежності. Греко-католицька церква закидала керівництву УТП, що воно "йрацює з йравославними” (ЦДАГО, 269-2-269: 67; Кулеба, 2007: 28). Через ці суперечності почали 
виникати самостійні організації - Українська майиия (Баня-Лука), грекокатолицька читальня ім. Маркіяна Шашкевича в Козарцю, Українське культурно-просвітне товариство ім. Тараса Шевченка в Прняворі, студентські товариства Пробоєм і Днійро (Ліський, 2002: 40; Liski, 2003-2004: 67). На грунті непорозуміння керівництво загребської Просвіти $и$ вдавалося до адміністративних заходів. У листопаді 1937 р. управа Врбаської бановини у Баня Луці за наполяганням управи УТП, яка посилалася на нібито суперечності у статуті УТП, заборонила діяльність їі філій у деяких боснійських населених пунктах. Замість них активну культурно-освітню діяльність роз-

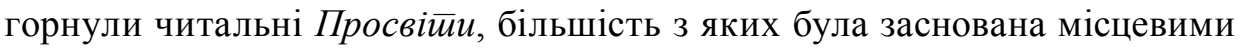
греко-католицькими парафіями. Після скасування заборони на діяльність філій у 1939 р. вони відновили свою роботу (Терлюк, 2002: 82). Діяльність УТП у Загребі була припинена у 1941 p.

Місцевими осередками загребської Просвіӣи були їі філії. 31 грудня 1933 p. завдяки Михайлу Костюку у Козарцю припинило своє існування РНПД, що діяло з 1928 р., натомість відкрилася філія УТП. У червні наступного року вона мала вже 80 членів (ЦДАВО, 4465-1-192: 3зв). При філії діяв драматичний гурток. Наприкінці 1937 р. місцева влада заборонила діяльність філії, у лютому 1939 р. відновила. До складу управи відновленої філії увійшли о. Є. Легенький (голова), Григорій Барщевський (заступник), Володимир Ментус (секретар), Микола Пахлєвський (скарбник), Марина Барщевська (бібліотекар), Петро Мирецький, Ілля Карасій (члени), ревізійної комісії Микола Чернявський та Анна Голик. М. Пахлєвський - делегат від філії до загальних зборів УТП у Загребі (3 журналів, 2008: 177).

У 1934 р. відкрилося одразу 6 філій. 15 лютого заходами Петра Шлапака була заснована філія УТП у Штрбцях. У червні 1934 р. вона мала 65 членів (ЦДАВО, 4465-1-192: 3зв). У березні 1937 р. до складу управи філії належали Василь Маланчук (голова), Сильвестр Маланчук (заступник), Володимир Соболь (секретар), Степан Каваць (скарбник), Степан Сеник (бібліотекар), ревізійної комісії - Василь Федьчишин і Василь Фаріон. Михайло Данчук - делегат від філії на загальні збори УТП у Загребі. У квітні 1939 р. місцева влада затвердила статут бібліотеки-читальні філії УТП у Штрбцях (3 журналів, 2008: 162-163, 180-181).

4 березня 1934 р. була заснована філія УТП у Муїнцях. У червні того ж року до складу її управи були обрані Василь Мельник (голова), Йосип Ляхович (заступник), Іван Зарванський (секретар), Василь Букало (скарбник), Іван Сенчук (бібліотекар), ревізійної комісії - Свстахій Мельник та Андрій Фетенко. Влітку 1934 р. філія мала 63 члени, в тому числі 19 жінок. Проте статут філії був затверджений лише 1 липня 1936 р. (АJ, 66-311-527). 
11 березня 1934 р. відкрилася філія УТП у Прняворі. У червні того ж року вона мала 58 членів (ЦДАВО, 4465-1-192: З3в). У цьому боснійському місті бібліотека-читальня Просвіти $и$ була започаткована ще 1909 р. Вона підпорядковувалася УТП у Львові. До її першого керівного складу увійшли Василь Семак, Степан Грицай, Дмитро Германюк, Іван Рудник, Степан Хомишин, Іван Свінський, Іван Ардан, Гринько Маланчук, Дмитро Фарина, Михайло Маланчук, Михайло Заболотний та Олекса Косаревич (Кулеба, 2007: 21).

Оскільки в середині 1930-х рр. керівники філій УТП у Боснії більше переймалися вирішенням економічних проблем своїх членів, заснуванням кооперативів, ощадно-позичкових кас, торговельних і ремісничих об'єднань, а провід УТП у Загребі більше уваги приділяв суспільно-політичній роботі, то між ними виникали певні суперечки (І. Г., 1936: 6). 3 метою їх припинення 18 липня 1935 р. у Прняворі відбулася спільна нарада представників осе-

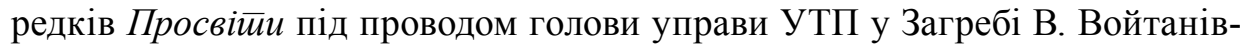
ського. У ній взяли участь делегати із Загреба, Брезіка, Вареш-Майдану, Гаєві, Детляка, Камениці, Козарця, Лішні, Лужанів, Муїнців, Прнявору, Опс'єчка, Расавця, Старої Дубрави, Хорвачан та Штрбців. Осип Коропей виголосив доповідь про становище української нації на еміграції, зокрема в Югославії, В. Войтанівський - про релігійні суперечки, що заважають консолідації українських національних сил, Андрій Пелліх - про поширення серед емігрантів й української національної меншини в Югославії культурно-освітньої діяльності, Ілля Гемон - про заснування кооперативів серед українців у Боснії та Славонії, Іван Каган - про необхідність будівництва домів під бібліотеки-читальні, Василь Семак - про потребу консолідації всіх українців. Наслідком наради стала координація дій центральної організації та місцевих осередків УТП у різних сферах діяльності у 1936 p. (Liskij, 2008: 61-62).

У 1937 р. до керівного складу філії УТП у Прняворі були обрані Ярослав Фарина (голова), Василь Микитишин (заступник), Ілля Гемон (секретар), Олекса Микитишин (скарбник), Стефан Свідерський (бібліотекар), Антон Коростіль і Микола Небесний (члени), ревізійної комісії - Іван Свідерський та Іван Рожко. Григорій Миськів - делегат від філії до загальних зборів УТП у Загребі (3 журналів, 2008: 161).

31912 р. у Прняворі діяла Українська ощадно-позичкова каса (кредитний кооператив). 24 березня 1935 р. на її базі місцева філія УТП заснувала Українську селянську ощадну касу. До її управи увійшли і члени керівних органів філії УТП І. Свідерський, В. Микитишин, Г. Миськів, пізніше - ще й М. Небесний (Кулеба, 2007: 34-35). 
2 липня 1936 р. у Прняворі за сприяння місцевої греко-католицької парафії була заснована Українська читальня. На початку 1937 р. і1ї статут було опубліковано на сторінках часопису Ріgне слово (Правила, 1937: 3). У 1938 p. читальня мала 52 члени (Liskij, 2008: 65). У 1937 р. філія УТП у Прняворі організувала дитячий садок під керівництвом студентки медичного факультету Загребського університету О. Колішицької, спортивну і музичну секції (3 журналів, 2008: 157).

9 квітня 1934 р. була заснована філія УТП у Баня-Луці, яка мала всього 10 членів (ЦДАВО, 4465-1-192: 3зв). Очолював управу філії Максим Війтюк. Невдовзі вона припинала існування. Більшість місцевих українців підтримала греко-католицьких священиків, які вважали, що центральна організація УТП повинна перебувати там, де проживає більшість українців, тобто в Баня-Луці або Прняворі, а не в Загребі (Liskij, 2008: 60-61). Тому наступного року була створена самостійна організація Украӥнська Майиия.

12 червня 1934 р. завдяки заходам Івана Яцуся була відкрита філія УТП у Камениці (ЦДАВО, 4465-1-312: 1зв). Ї̈̈ керівником був о. Свстахій Легенький. Саме завдяки його ініціативі у селі було встановлено пам'ятник Моїила на честь полеглих борців за українську державність. 21 вересня 1936 р. на урочистому відкритті Моїили були присутні представники Української студентської громади в Загребі, філій УТП у Гаєві, Муїнцях, Прняворі, Старій Дубраві, Хорвачанах, Штирбцях (більше 700 осіб) (3 журналів, 2008: 143-145).

26 червня 1934 р. була заснована філія УТП у Старій Дубраві (ЦДАВО, 4465-1-312: 1зв). Ї̈̈ очолювали Петро Яловий та о. Іван Левицький.

15 грудня 1935 р. відкрилася філія УТП у Хорвачанах. До ініціативної групи належали Олекса Бобрек, Олекса та Петро Бортник, Іларіон Бригадир, Іван Гайдукевич, Адам Дерен, Кость Заставний, Іван Калинюк, Петро Комаревський, Іван та Максим Корпак, Яків Курцеба, Олекса і Стефан Лаврів, Іван Новосад, Микола Пронь, Федір Сенишин, Іван та Степан Сікора, Іларіон Стасюк, о. Василь Стрільчик, Петро Федорак та Павло Фігурек. До складу управи були обрані І. Гайдукевич (голова), Я. Курцеба (заступник), О. Лаврів (секретар), К. Заставний (скарбник), І. Стасюк (бібліотекар), I. Калинюк, І. Корпак, С. Лаврів, С. Сікора та Ф. Сенишин (члени), ревізійної комісії - І. Новосад (голова), П. Бортник, М. Пронь (члени). 14 лютого 1937 p. філія мала вже 47 членів. До складу управи входили І. Гайдукевич (голова), П. Бортник (заступник), Ф. Сенишин (секретар), С. Лаврів (скарбник), I. Стасюк (бібліотекар), ревізійної комісії - О. Лаврів (голова), К. Заставний та Я. Куцеба (АЈ, 66-311-527). У січні 1939 р. філія мала 50 членів. До складу управи належали о. В. Стрільчик (голова), П. Бортник (заступник), І. Гайдукевич (секретар), С. Лаврів (скарбник), М. Пронь (бібліотекар), П. Корпак, 
С. Сікора, Матвій й Олекса Бортники, Степан Корній (члени), ревізійної комісії - І. Калинюк, Степан Канюка та І. Стасюк (Ів-ич, 1939: 10).

22 березня 1936 р. була заснована філія УТП у Гаєві (Хорив, 1943а: 8). Наступного року вона перетворилася на Українську читальню. У березні 1937 р. читальня мала 30 членів, до складу її управи входили Степан Береза (голова), Степан Дерех (заступник), Теодор Курман (секретар), Іван Сеньчук (скарбник), Михайло Пацюк (бібліотекар), Микола Явний (член), ревізійної комісії - Остап Бородій, Павло Новицький та Іван Баран. У січні 1939 р. читальня мала 46 членів, до складу їі управи належали Василь Демянчук (голова), П. Новицький (заступник), Михайло Романків (секретар), Степан Пацюк (скарбник), Степан Моравський (бібліотекар), ревізійної комісії - Т. Курман, М. Явний та Степан Лотачевський (3 журналів, 2008: 164, 175).

Організаційну роботу щодо створення філій у Шумече та Каніжі розпочав навесні 1936 р. член УСГ у Загребі, студент медичного факультету Загребського університету Андрій Пелліх. Влітку того ж року разом 3 ним прибули члени УСГ у Загребі Всеволод Левицький та Зенон Фалендиш. Перший зайнявся загальними організаційними справами, другий влаштував дитячий садок (близько 50 дітей), третій організував музично-танцювальні курси для дітей. Плідна культурно-освітня діяльність студентів дала позитивний результат. 22 листопада 1936 р. відбулися установчі збори, на яких був присутній представник управи УТП у Загребі Осип Коропей. Вони і започаткували філію УТП у Шумече. До складу управи були обрані Гнат Фарина (голова), Степан Максимчук (заступник), Дмитро Сушко (секретар), Павло Фарина (скарбник), Мільон Луців (бібліотекар), Теодор Романів і Степан Торконяк (запасні члени), ревізійної комісії - Пилип Романів та Михайло Сушко. Павло Фарина - делегат на загальні збори УТП у Загребі.

У середині вересня 1937 р. відбулися установчі збори філії УТП у Каніжі. Вітальне слово виголосив о. Микола Орос. Привітав місцевих українців 3 відкриттям філії і член центральної управи УТП у Загребі Євген Мацях. До управи філії були обрані о. М. Орос (голова), Петро Поляк (заступник), Семен Застрижений (секретар), Петро Волохач (скарбник), Михайло Семків (бібліотекар), Петро Грамняк та Іван Бойко (запасні члени), ревізійної коміciї - Осип Мочук і Петро Застрижений. Іван Майбуга - делегат на загальні збори УТП у Загребі. Вступний внесок складав 5 динарів, щорічний внесок - 12 динарів (Liskij, 1990-2000: 296-297).

У деяких населених пунктах проживали неорганізовані у місцеві формальні структури (філії, відпоручництва) члени або прихильники УТП у Загребі. Зазвичай це були села з невеликою кількістю українців, зокрема Буковац, Вареш-Майдан, Вучіяк, Подграде, Раковац, Селіште та Серджевиці (3 журналів, 2008: 156, 158, 159, 168, 169, 182). 


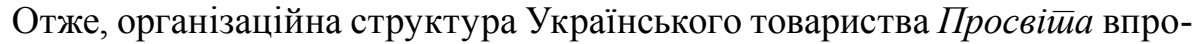
довж усього міжвоєнного періоду була мінливою. Спочатку центральна управа УТП перебувала в Загребі, у другій половині 1920-х рр. - в Белграді. Після заборони у 1932 р. центральної організації УТП в югославській столиці її функції знов перебрав на себе осередок у Загребі. Він розгорнув активну діяльність з розбудови Просвіти . Було відкрито декілька філій і представництв. Загальна кількість членів УТП сягнула 1 тис. осіб. Серед них переважали русини й українці, які прибули до Югославії в середині XVIII - на початку XX ст., меншу частину складали емігранти із Східної Галичини та Наддніпрянської України. Між центральною управою УТП у Загребі та керівниками окремих філій існували розбіжності щодо спрямування діяльності організації. Перша намагалася її політизувати, другі - обмежитися культурно-освітньою роботою.

\section{ДЖЕРЕЛА I ЛІТЕРАТУРА}

Архив Југославије (АЈ), ф. 14, фасцикле (фасц.) 64, јединица описа (j. о.) 204.

AJ, ф. 66, фасц. 311, ј. о. 527.

Дописі (1925). Дойисі. Украӥнський йрайор (Берлін), 10 (15 мая), 4.

3 громадського (1932). 3 громадського життя української еміграції в Югославії. Труgова Україна (Прага), 5-6 (травень-червень), 26.

3 журналів (2008). 3 журналів і книжок. In: Маиееріали gо ісйорії украӥнців у Боснії, $T$.

5. Новий Сад: Руске слово - Грекокатолицька парафія св. Петра і Павла, 109-183.

3 нашого (1934). 3 нашого життя. Хроніка. Гурток ст. пл. "Перелетні" в Загребі. Пласйові вістиі (Праїа), 3, 6.

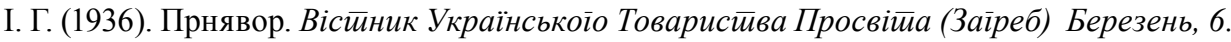

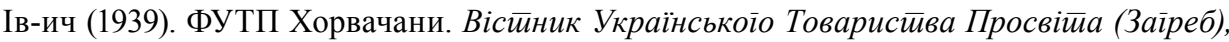

Березень-квітень, 10.

Короткий (1936). Короткий огляд діяльности пластових частин СУПЕ в минулому пл.

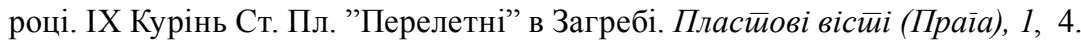

Кулеба Є. (2007). 100 років "Просвіті": 3 нагоди відзначення 100-річчя від заснування

Товариства "Просвіта" у Боснії. Кула: Газетно-видавнича установа Рigне слово.

Кульчицький Є. (1951). Перша пластова еміграція. Пласиовий шлях (Мюнхен), 5, 29-35. Латяк Ю. (2002). Інформування українською мовою на теренах колишньої Югославії (1922-1992): Короткий огляд. Думки з Дунаю (Вуковар), 5: 51-55.

Лимар С. (1923). Українські студенти в Юго-Славії. Український сйуgенй (Прайа), 3-4 (жовиенен-листиойаg), 68-69.

Ліський Б. (2002). 3 діяльності українських студентів у Хорватії (1920-1945). In: Укра-

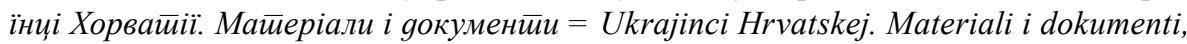
Кн. 1, Загреб: Grafika, 38-50.

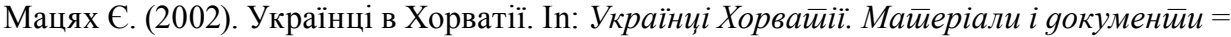
Ukrajinci Hrvatskej. Materiali i dokumenti, Кн. 1, Заїpeб: Grafika, 51-61. 
Пагу-ангаре (1936). Український Пласт в Югославії (IX. К. ст. пл. «Перелетні» в Загребі). Пластиові вістиі (Праїа, 9, 12-13.

Правила (1937). Правила Української Читальні у Прняворі. Ріgне слово, 1, 3.

Протест (1927). Протест. Тризуб (Париж), 29, 3-7.

Різні вісти (1926). Різні вісти. Українське товариство «Просвіта» у Білгороді. Украӥнський ӣрайор (Берлін). 4 (15 люӣо̄̄o), 4.

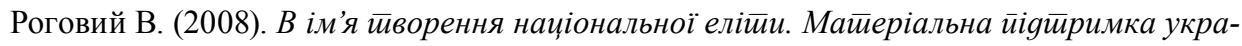
їнськойо сйуденйстива на чужині в 1920-1991 роках. Київ: ПП Сергійчук М.I.

Терлюк I. (2002). "Просвіта" - берегиня національної ідентичності. In: Украӥнці Хорва-

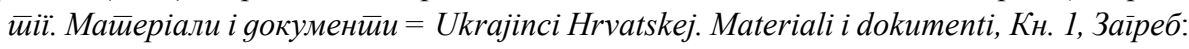
Grafika, 74-83.

Хорив (1943а). Українська еміграція в Югославії. Український вісник (Берлін). 2 (24 січня), 5-8.

Хорив (1943b). Українська еміграція в Югославії. Украӥнський вісник (Берлін). 3 (7 люüō̄o), 3-7.

Хроніка (1932). Хроніка. 3 життя української еміграції. В Югославії. Річні загальні збори т-ва «Просвіта» у Новому Саді. Тризуб (Париж). 17, 15.

Хроніка (1933). Хроніка. 3 життя української еміграції. В Югославії. Загальні збори Українського Товариства «Просвіта» в Новому Саді. Тризуб. 16-17, 30.

Центральний державний архів вищих органів влади та управління України (ЦДАВО), ф. 3905 , оп. 2, спр. 165,38 арк.

ЦДАВО, ф. 4465, оп. 1, спр. 192, 3 арк.

ЦДАВО, ф. 4465, оп. 1, спр. 312, 4 арк.

Центральний державний архів громадський об’єднань України (ЦДАГО), ф. 269, оп. 2, спр. 258, 204 арк.

ЦДАГО, ф. 269, оп. 2, спр. 262, 119 арк.

ЦДАГО, ф. 269, оп. 2, спр. 268, 204 арк.

ЦДАГО, ф. 269, оп. 2, спр. 269, 300 арк.

ЦДАГО, ф. 269, оп. 2, спр. 270, 276 арк.

ЦДАГО, ф. 269, оп. 2, спр. 271, 206 арк.

ЦДАГО, ф. 269, оп. 2, спр. 272, 171 арк.

ЦДАГО, ф. 269, оп. 2, спр. 275, 215 арк.

ЦДАГО, ф. 269, оп. 2, спр. 276, 183 арк.

ЦДАГО, ф. 269, оп. 2, спр. 277a, 171 арк.

ЦДАГО, ф. 269, оп. 2, спр. 278, 208 арк.

ЦДАГО, ф. 269, оп. 2, спр. 282, 242 арк.

Hrvatska Republika - Hrvatski državni arhiv (HR-HDA), f. 1353, inv. br. 3399, 73 list.

HR-HDA, f. 1353, inv. br. 3908, 24 list.

Liski B. (2003-2004). Anton Ivahnjuk, veliki ukrajinsko-hrvatski domoljub. Думки з Дунаю = Misli s Dunava. 6: 64-79.

Liskij B. (1990-2000). Filijale zagrebačkoh društva Prosvita u Šumeću i Kanjiži. Думки 3 Дунаю = Misli s Dunava (Вуковар), 3, 294-298.

Liskij B. (2008). Djelovanje ukrajinskoh društva «Prosvita» iz Zagreba među Ukrajincima u Bosni i Hercegovini između dvaju ratova. In: Майеріали gо іситорії українців у Боснії, T. 5. Новий Саg: Руске слово - Грекокайолищька иарафія св. Пейра і Павла, 53-67. 
Valeriy Vlasenko

\title{
UKRAINIAN SOCIETY PROSVITA IN ZAGREB IN 1922-1941. (ORGANIZATIONAL STRUCTURE)
}

\begin{abstract}
SUMMARY
The first public organization of Ukrainian political emigration in the Kingdom of Serbs, Croats and Slovenes was established in 1922 in Zagreb. It was the Ukrainian society Prosvita. Several regional branches were established subsequently, including in Belgrade. The number of members of branches was bigger than in the central organization in Zagreb. Therefore, in early 1928, Belgrade became the seat of the central organization Prosvita. Its council included representatives of different social and political environments - supporters of the hetman P. Skoropadsky and the Government of the UPR in exile. This fact has led to sharp contradictions between them. Some members withdrew from Prosvita and formed the Ukrainian community. In June 1932, the Serbian authorities banned the activities of Prosvita in Belgrade. The initiator of the restoration of the central organization was the branch of Prosvita in Zagreb. In the early 1930s, the number of its members increased annually due to the arrival of Ukrainians from Eastern Galicia Ukrainian and Ukrainian emigrants from different European countries to study at the local university. In June 1933, a new statute of Prosvita was adopted, and the Croatian authorities approved it. Then, the organizational structure of Prosvita began to develop actively, mainly in Bosnia and Croatia. In 1937, Prosvita had eight branches and several offices. The total number of its members reached one thousand people. Rusyns and Ukrainians who came to the region in the middle of the 18th $20^{\text {th }}$ century prevailed among them. The Ukrainian emigrants from Eastern Galicia and Dnieper Ukraine formed the minority. Prosvita in Zagreb ceased to exist in 1941.
\end{abstract}

Keywords: Belgrade, Zagreb, Kingdom of Serbs, Croats and Slovenes, Rusyns, Ukrainian emigration, Ukrainian society Prosvita, Yugoslavia. 